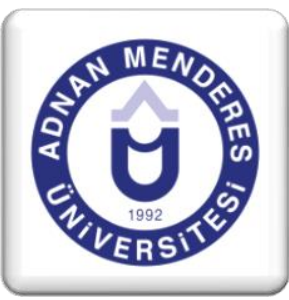

\section{Ergenlerde Görülen Saldırgan Davranışlarda Ebeveyn ve Ergenlere Uygulanan Psikoeğitim Programının Etkisinin İncelenmesi ${ }^{1}$}

\author{
Suat KILIÇARSLAN ${ }^{2,}$ Meral ATICI ${ }^{3}$
}

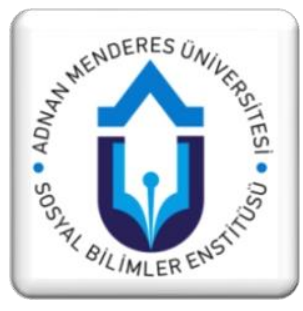

\title{
ÖZET
}

Bu araștırmada, saldırgan davranışları olan ergenlere yönelik sistemik aile terapileri kuramlarına dayalı olarak oluşturulan "Şiddet ve Saldırganlıkla Baş Etme" programı ve bu ergenlerin ebeveynlerine yönelik "Şiddetsiz Karşı Koyma" ebeveyn programı uygulanmıştır. Bu programların ergenlerde görülen saldırganlık, annebabalarının ebeveynlik rolüne ilişkin kendilik algıları, aile ilişkileri ve anne-baba stres düzeyleri üzerindeki etkisi incelenmiştir.

Araştırmanın verileri deney ve kontrol grubunda bulunan öğrencilere uygulanan 'Saldırganlık Ölçeği', ve ebeveynlere uygulanan 'Anne-Baba Stres Ölçeği', 'Aile Değerlendirme Ölçeği' ve 'Ebeveynlik Rolüne İlişkin Kendilik Algısı Ölçeği’ aracılığıyla elde edilmiştir. Söz konusu ölçekler deney ve kontrol grubu ergen ve annebabalarına öntest, sontest ve izleme ölçümleri olarak uygulanmıştır. Araştırma verilerinin analizinde SPSS 17 paket programı kullanılmıştır. Bulgular incelendiğinde, ergen ve anne babalarına uygulanan programların ergenlerde görülen saldırgan davranışları azalttığı, ana-babalarının ebeveynlik becerilerini ve aile ilişkilerini geliştirdiği ve anne-baba stres düzeylerini anlamlı derecede düşürdüğ̈̈ ve bu etkinin uzun süreli olduğu görülmüştür. Bu sonuçlardan hareketle özellikle ergenlere yönelik hizmet veren tüm kurumlarda, bu programların anne-babalarla işbirliği çerçevesinde uygulanması önerilmektedir. Ergenlerde görülen şiddet ve saldırganlık problemlerinin azaltılmasında, yapıcı ve sıcak ilişkilerin kurulduğu aile ortamının oluşturulması ve ebeveynlik becerilerinin geliştirilmesinin faydalı olabileceği düşünülmektedir.

Anahtar kelimeler: Şiddet, saldırganlık, şiddet ve saldırganlıkla baş etme programı, şiddetsiz karşı koyma ebeveyn programı.

\section{Investigating of The Effects of Psycho-Educational Programme That is Applied to Parents and Adolescents Towards Reduction of Aggressive Behavior in Adolescents}

\begin{abstract}
In this study "a program of dealing with violence and aggressiveness" based on systemic family therapy theories was applied to the adolescents with violent and disruptive behaviors and "Non-violent resistance" parent program for the parents of those adolescents were applied. The effects of these programs on violence shown by adolescents, and family relationships, parents' perception of parenthood role and stress levels of parents were examined.

The data for the study were obtained by the scales administered to the students and parents in experimental and control groups. The scales were applied to students and parents who were in experimental and control groups as a pre-test, posttest and follow up measures. For the analying of the quantitative data, SPSS 17 program was used. Results showed that aggressive behaviors seen in adolescents were decreased, parenthood skills and the family relationships of the parents were improved, stress levels of parents were decreased significantly, and these effects were prolonged. Considering these results it was suggested that the programs should be used with the cooperation of parents at all the institutions aimed to help specially for the adolescents and it was considered that it would be helpful to decrease the violence and aggressiveness proble ${ }^{4} \mathrm{~ms}$ seen in adolescents, to decrease the stress levels of the parents, to establish a family atmosphere where constructive and warm relationships are established and to improve parenthood skills.
\end{abstract}

Keywords: Violence, Aggressiveness, Nonviolent Resistance Programme, Adolescent Psycho-education Programme.

\footnotetext{
${ }^{1}$ Bu makale, Çukurova Üniversitesi, Sosyal Bilimler Enstitüsü tarafindan Ocak 2016 tarihinde kabul edilen doktora tezinin bir bölümüdür ve 08-10 Şubat 2016 tarihlerinde İstanbul'da gerçekleştirilen INTCESS2016- 3rd International Conference On Education And Social Sciences' te özet sözel bildiri olarak sunulmuştur. 2 Gazi İlkokulu, Niğde, suatkilicarslan@hotmail.com

3 Çukurova Üniversitesi, Eğitim Fakültesi, Rehberlik ve Psikolojik Danışmanlık ABD, matici@cu.edu.tr
} 


\section{Giriş}

Sanayileşme ve bunun sonucu olarak ortaya çıkan kentleşme olgusu aile yaşamını karmaşık hale getirmektedir. Böyle toplumlarda uyum içerisinde yaşayabilmek için bireylerin kendi kendini yönetebilme becerilerinin gelişmesi gerekmektedir. Sağlıklı bir aile ortamı ve etkileşim örüntüsü içerisinde gelişemeyen çocuk güçlüklerle karşılaştığında zaman zaman şiddet ve yıkıcı davranışlar sergileyebilmektedir. Saldırganlık, bireylerin başkalarını incitmeyi amaçladığı her türlü davranış olarak tanımlanmaktadır (Freedman, Sears ve Carlsmith, 1989). Riches (1986), saldırganlığın insanın sosyal çevresini değiştirmek için kullandığı bir araç olduğunu vurgulamaktadır. Freud'a göre saldırganlık, insanın kendine yönelik olan yıkıcı eğilimlerinin dış dünyadaki nesnelere çevrilmesidir (Geçtan, 1992). Adler ise saldırganlığı, kendi ihtiyaçlarını karşılama isteğinden kaynaklanan ve engellenmeler sonucu başvurulan bir dürtü olarak ele almaktadır (Gümüş, 2000).

Ülkemizde son yıllarda aile içinde ve okullarda saldırganlık ve şiddet içeren davranışlarda artış görülmektedir (Kabasakal, 2013). Çocukluk ve ergenlik dönemindeki davranış sorunları; genetik, biyolojik ve sosyal faktörlerin (işsizlik, yoksulluk, anne-babanın düşük eğitim seviyesi, eşler arası çatışmalar, boşanmalar, anne-babalık rolü ve yaşanan stres vb.) yanı sıra aile içindeki olumsuz iletişim örüntüleri ile de ilişkilendirilmektedir. Bu süreçte özellikle anne-baba ve ergen arasındaki iletişim örüntüleri sağlıklı bir biçimde düzenlenerek ve ergenlere davranışlarını kontrol edebilmelerine yönelik bazı beceriler kazandırılarak bu kısır döngünün kırılması söz konusu olabilmektedir (Baltac1, 2011; Özmen, 2004).

Ergenlik dönemi, karşılaşılan problemler ve geliştirilmesi gereken çözüm yolları bakımından zorlu yaşam dönemlerinden biridir (Kulaksızoğlu, 2002). Bireylerin ergenlik döneminde karşılaşacağı güçlükler ile daha kolay bir şekilde baş edebilmesi açısından bireysel olarak farkındalıklarının arttırılması, kendine güven duygularının geliştirilmesi, iletişim ve empati becerilerinin geliştirilmesi, kaygıyla baş edebilme, öfke duygularıyla olumlu bir biçimde baş edebilme ve çatışma çözme becerilerinin geliştirilmesi gibi konularda kimi zaman desteğe ihtiyaçları olabilmektedir. Bu destek ergenin ailesinden, yasadığı sosyal cevreden gelebilirken; bazen de çeşitli psikolojik danışma ve rehberlik hizmetleri bu desteği sağlayabilmektedir (Gündoğdu, 2009). Dodge ve Frame (1982) ve Farrington (1991) saldırganlık ve şiddet gibi olumsuz davranışları çözmedeki en temel engelin öğrencilerin çatışma çözme, problem çözme ve iletişim gibi yaşam becerilerindeki yetersizlikleri olduğunu ifade etmektedirler.

$\mathrm{Bu}$ süreçte anne baba ve ergen arasında ilişkilerin yapısı ve etkileşim biçimi de çok önemlidir. Anne-babaların tutumlarının çocukların davranış sorunlarının oluşumundaki etkisi göz önüne alındığında, davranış sorunlarına müdahalede çocuklarla birlikte anne-babaların davranışlarının biçimlendirilmesinin de gerekliliği ortaya çıkmaktadır (Arkan ve Üstün, 2009). Bu araştırmada şiddet ve saldırganlık, sadece bir birey sorunu olarak değil, aynı zamanda bir aile ve ailenin de içinde bulunduğu toplumsal ve kültürel bir yapı sorunu olarak ele alınmaktadir.

Saldırganlık içeren yıkıcı davranışları olan ergen çocuklara sahip ebeveynler, çocuklarının alacağı beceri eğitimlerinin yanı sıra kendileri de katılacakları eğitim ve destek programlarından yararlanabilir ve aile içi etkileşimlerinde olumlu yönde değişiklikler sağlayabilirler. Anne baba eğitimi; anne ve babaya çocuğun gelişimi, aile ilişkileri, anne baba tutum ve davranışları gibi konularda gerekli bilgi, tutum ve becerilerin sistemli bir biçimde kazandırılmasıdır. Anne baba eğitiminin temel amacı; anne babaların özgüvenini geliştirmek, olumsuz tutum ve davranışlarını değiştirmek, anne babaları çocuk gelişimi ve eğitimiyle ilgili konularda bilgilendirerek desteklemek ve bu yolla ebeveyn çocuk 
etkileşimini artırmaktır. Dolayısıyla anne babaların çocuklarına karşı olumlu tutum geliştirebilmeleri, anne baba olmanın önemini anlamaları, çocuklarıyla sağlıklı iletişim kurabilmeleri ve çocuklarının eğitiminde etkin rol oynayabilmeleri anne babalara verilen eğitimle sağlanabilmektedir (Çağdaş ve Seçer, 2006).

Alan yazın incelendiğinde ülkemizde ve dünyada ergenlerde görülen şiddet ve saldırganlıkla baş etmeye yönelik bir çok program olduğu görülmektedir. Bireysel düzeydeki programlardan bazıları; okul temelli sosyal gelişim programları, yaşam becerileri eğitimi, çatışma çözme becerileri eğitimi, öfke yönetimi, problem çözme becerileri eğitimi, iletişim becerileri eğitimi, akran eğitimi gibi okul temelli programlardır (Özmen, 2004; Duran ve Eldeleklioğlu, 2005; Smeijsters ve Cleven, 2006; Fong, 2006; Uysal, 2006; Tekinsav-Sütçü, 2006; Ando, Asakura, Ando ve Simons-Morton, 2007; Akdeniz, 2007; Güner, 2007; Horne, Stoddard ve Bell, 2007; Gültekin, 2008; Karataş ve Gökçakan, 2009; Gündoğdu, 2009; Yavuzer ve Üre, 2010; Taner-Derman, 2011; Bedel ve Arı, 2012; Türk, 2013). Bir diğer grupta; ev ziyaretleri, aile eğitimleri, aile terapisi gibi aile katılımını hedef alan aile temelli programlar yer almaktadır. Uluslararası alan yazındaki meta-analitik çalışmalar incelendiğinde, öğrenci ve ailelere yönelik önleme ve müdahale programlarının saldırganlık ve şiddet davranışlarını azaltmada etkili yöntemler olduğu ve saldırganlığı olan çocuk ve gençler için olumlu sonuçlar sağladığını ortaya koymaktadır (McCart, Prienter, Davies ve Azen, 2006; Scheckner, Rollin, Kaiser-Ulrey ve Wagner, 2002; Sukhodolsky, Kassinove ve Gorman, 2004; Şahin \& Kalburan, 2009; Wilson, Gottfredson ve Najaka, 2001; Wilson ve Mark, 2007). Bacıoğlu (2014)'nun yapmış olduğu meta-analitik çalışmada Türkiye'de şiddet ve saldırganlığın azaltılmasında önleme ve müdahale programlarının çok olumlu etkilerinin olduğunu göstermektedir.

Özetle, saldırgan ve öfkeli davranışlar, ülkemiz için önemli toplumsal problemlerdendir. $\mathrm{Bu}$ sorunun erken ve en etkili biçimde çözülebilmesi için müdahale çalışmaları gerekmektedir. Bu bağlamda ergenlere yönelik okul temelli önleme programlarının ve saldırgan davranışlara sahip çocukları olan anne-babaların aile içi etkileşim becerilerinin geliştirilmesine yönelik psikoeğitim destek programlarının çok önemli olduğu düşünülmektedir. Özellikle, bu tür psiko-sosyal destek programları ergenlik döneminde saldırgan davranışları artmış çocukları olan ebeveynlerin yaşamış oldukları çaresizlik duyguları ve stres ile baş etmede, ebeveynlik ve aile içi etkileşim becerilerini artırmada, öğrencilerin sağlıklı gelişimlerine katkıda bulunmada ve ebeveynlerin anne-baba-ergen arasında yaşanan sorunlarla daha kolay başa çıkabilmelerinde yardımcı olabilmektedir. Ülkemizde ergen bireylerde görülen şiddet ve saldırganlık içeren davranışları önleme ve müdahaleye yönelik program ve araştırmaların sayıca az olduğu, anne-baba ve ergenlerin bütüncül bir bakış açısı ile birlikte ele alındığı araştırmaların ise olmadığı ve aile süreçlerini birlikte ele alan araştırmalara ihtiyaç olduğu düşünülmektedir.

$\mathrm{Bu}$ amaçla, bu çalışmada lise örgencilerine yönelik saldırgan davranışların azaltılması amacıyla hazırlanmış olan 'Şiddet ve Saldırganlıkla Baş Etme Programı'nın ve bu öğrencilerin anne-babalarına yönelik aile içi ilişkilerin geliştirilmesi, ebeveyn rolüne ilişkin kendilik algılarının arttırılması ve anne-baba stres düzeyinin azaltılmasını amaçlayan 'Şiddetsiz Karşı Koyma' ebeveyn programının etkililiğini incelemek bu araştırmanın problemini oluşturmaktadır. 


\section{Araștırmanın Amacı}

$\mathrm{Bu}$ araştırmanın amacı, ergenler için hazırlanan 'Şiddet ve Saldırganlıkla Baş Etme Programı' ve şiddet ve yıkıcı davranışları olan ergenlere sahip ebeveynlere yönelik geliştirilmiş olan 'Şiddetsiz Karşı Koyma' ebeveyn programının; ergenlerin saldırganlık içeren tutum ve davranışlarının azaltılması, ergen-ebeveyn arasında aile içi ilişkilerin geliştirilmesi, anne-babaların ebeveynlik rolüne ilişkin kendilik algılarının geliştirilmesi ve ebeveyn stres düzeyinin azaltılmasıdır.

Araştırmada, probleme dayalı olarak programların etkililiğine ilişkin geliştirilen denenceler aşağıda yer almaktadır.

Denence 1: Şiddet ve saldırganlıkla baş etme programının uygulandığı deney grubu öğrencilerinin, kontrol grubu öğrencilerine göre 'Saldırganlık Ölçeği’nden aldıkları sontest puanları öntest puanlarından anlamlı düzeyde düşüktür ve bu fark üç ay sonra yapılan izleme ölçümünde de devam etmektedir.

Denence 2: Şiddetsiz karşı koyma programının uygulandığı deney grubu ebeveynlerinin kontrol grubu ebeveynlerine göre 'Ebeveynlik Rolüne İlişkin Kendilik Algısı Ölçeği, Rol Doyumu, Yeterlik, Yatırım ve Rol Dengeleme Alt Boyutlarından aldıkları sontest puanları öntest puanlarından anlamlı düzeyde yüksektir ve bu fark üç ay sonra yapılan izleme ölçümünde de devam etmektedir.

Denence 3: Şiddetsiz karşı koyma programının uygulandığı deney grubu ebeveynlerinin kontrol grubu ebeveynlerine göre 'Aile Değerlendirme Ölçeği’nden aldıkları sontest puanları öntest puanlarından anlamlı düzeyde düşüktür ve bu fark üç ay sonra yapılan izleme ölçümünde devam etmektedir.

Denence 4: Şiddetsiz karşı koyma programının uygulandığı deney grubu ebeveynlerinin kontrol grubu ebeveynlerine göre 'Anne-Baba Stres Düzeyi Ölçeği'nden aldıkları sontest puanları öntest puanlarından anlamlı düzeyde düşüktür ve bu fark üç ay sonra yapılan izleme ölçümünde devam etmektedir.

\section{Yöntem}

\subsection{Araştırmanın Modeli}

Bu çalışmada, deneysel desen türlerinden biri olan "öntest-sontest kontrol gruplu (ÖSKD)" yarı deneysel bir model kullanılmıştır. Araştırmanın çalışma grubu, Adana'da bir ortaöğretim kurumunda 2014-2015 eğitim-öğretim yılında öğrenimlerine devam eden ve 'Saldırganlık Ölçeği' (SÖ) puanları ortalamanın üzerinde olan, araştırmaya katılmaya gönüllü dokuzuncu, onuncu ve on birinci sınıf öğrencileri ve onların ebeveynlerinden oluşmuştur. On ikinci sınıf öğrencileri mezun olma aşamasında olmaları, üniversite sınav hazırlığı içerisinde olmaları ve uygulanacak psikoeğitim programı sonrası izleme ölçümlerinin de yapılacak olması nedeniyle araştırma dışında bırakılmıştır. Saldırganlık Ölçeği, 9. 10. ve 11. sınıflardan toplam 696 öğrenciye uygulanmıştır. Ön ölçümler sonucunda SÖ puan ortalamalar1 110 ve üzeri olan yüz on öğrencinin araştırmaya katılmaya uygun olacağı görülmüştür. Bu yüz on ergen ve ebeveyni arasından araştırmaya katılmaya gönüllü 17 ergen ve 17 ebeveyn olmak üzere toplam 34 ergen ve 34 ebeveyn deney ve kontrol gruplarına atanmıştır. Ön ölçümlerin yapıldığı öğrencilerin sayıları, aritmetik ortalama ve standart sapma değerleri, minimum ve maksimum değerleri Tablo 1'de yer almaktadır. 
Tablo 1.Saldırganlık Ölçeğinden Elde edilen Puanların Aritmetik Ortalama, Standart Sapma ve Sayı Genişliği

\begin{tabular}{|c|c|c|c|c|c|}
\hline Ölçek & $\mathbf{N}$ & $\overline{\boldsymbol{X}}$ & Ss & Minimum & Maksimum \\
\hline SÖ & 696 & 85.42 & 19.37 & 51.00 & 158.00 \\
\hline SÖ & 110 & 116.06 & 11.71 & 105.00 & 158.00 \\
\hline SÖ & 34 & 123.47 & 14.34 & 105.00 & 156.00 \\
\hline
\end{tabular}

SÖ: Saldırganlık Ölçeği

Saldırganlık ölçeği puanları ortalamanın bir standart sapma üzerinde olan, araştırmaya katılmaya gönüllü öğrenci ve ebeveynler ile katılımcıların ergen ve ebeveyn gruplarına atanması işlemi denek çiftlerinin oluşturulması, yani eşleştirme yöntemine göre yapılmıştır. Yarı deneysel çalışmalarda katılımcıların çalışma gruplarına tesadüfi olarak atanması oldukça güçtür. Bağımlı değişken dışında bazı değişkenleri manipule etmek gerekebilir (Heppner, Wampold ve Kivlighan, 2013). Bu sebeple bu araştırmada cinsiyet, yaş, sınıf düzeyi, ekonomik gelir düzeyi, herhangi bir psikolojik yardım almıyor olmak gibi bazı değişkenler kontrol altına alınmıştır. Öğrenci grupları oluşturulurken cinsiyete yönelik eşleştirmeye dikkat edilmesine rağmen, ebeveyn gruplarında babaların birçoğu çalışma durumları ve meşguliyetlerinden dolayı grup programına devam edemeyeceklerini belirttiklerinden, ebeveyn grupları çoğunlukla annelerden oluşturulmuştur. Yani anne baba gruplarında deney ve kontrol grupları oluşturulurken cinsiyete göre yansız atama yapılamamıştır.

Ergenlere uygulanan SÖ ve ebeveynlere uygulanan ABSÖ ve ERKA-Yeterlik, Yatırım ve Rol Dengeleme alt ölçeklerinden alınan öntest puan ortalamaları normal dağılım özelliği gösterdiğinden deney ve kontrol gruplarının öntest puan ortalamaları arasındaki farka t testi ile bakılmış ve sonuçlar Tablo 2'de sunulmuştur.

Tablo 2.Deney ve Kontrol Grupları Ön Ölçümlerine Ait Puanlarının Aritmetik Ortalama, Standart Sapma ve t Değerleri

\begin{tabular}{|c|c|c|c|c|c|c|}
\hline \multirow[t]{2}{*}{ Ölçekler } & \multicolumn{2}{|c|}{ Deney Grubu } & \multicolumn{2}{|c|}{ Kontrol Grubu } & \multirow[t]{2}{*}{$\mathbf{t}$} & \multirow[t]{2}{*}{$\mathbf{p}$} \\
\hline & $\overline{\boldsymbol{X}}$ & Ss & $\overline{\bar{X}}$ & Ss & & \\
\hline SÖ & 119.7059 & 12.72185 & 127.2353 & 15.24602 & -1.563 & .128 \\
\hline ABSÖ & 39.1765 & 7.34196 & 37.2353 & 7.34447 & .771 & .447 \\
\hline ERKA-YET & 16.2941 & 3.31219 & 14.4706 & 3.82619 & .1486 & .147 \\
\hline ERKA-YAT & 12.8824 & 1.83311 & 12.2353 & 3.13308 & .735 & .468 \\
\hline ERKA-RDEN & 9.3529 & 12.72185 & 10.4118 & 3.26073 & -1100 & .280 \\
\hline
\end{tabular}

Tablo 2 incelendiğinde öğrencilere uygulanan SÖ ve ebeveynlere uygulanan ABSÖ, ERKA ölçeği yeterlik, yatırım ve rol dengeleme alt ölçeklerine ilişkin öntest puanları arasında deney ve kontrol grupları arasında anlamlı bir fark olmadığı ortaya çıkmıştır.

Ebeveynlere uygulanan ölçme araçlarından 'ADÖ' ve 'ERKA Ölçeği Rol Doyumu Alt Boyutu'nun öntest puan ortalamaları normallik sayıtlısını karşılamadığından deney ve kontrol gruplarının öntest puan ortalamaları arasındaki farka non-parametrik testlerden biri olan Mann Withney U testi ile bakılmış ve sonuçlar Tablo 3'te sunulmuştur. 
Tablo 3.Deney ve Kontrol Gruplarının Aile Değerlendirme Ölçeği ve Ebeveynlik Rolüne İlişkin Kendilik Algısı Ölçeği Rol Doyumu Alt Boyutu Öntest Puanlarına İlişkin Mann Whitney U Testi Sonuçları

\begin{tabular}{lllllll}
\hline Ölçüm & Gruplar & $\mathbf{n}$ & Sıra Ortalaması & Sıra Toplamı & U & p \\
ADÖ & Deney & 17 & 16.91 & 287.50 & 134.50 & .730 \\
& Kontrol & 17 & 18.09 & 307.50 & & \\
& & & & & & \\
\multirow{2}{*}{ Rol Doyumu } & Deney & 17 & 20.00 & 340.00 & 102.00 & .141 \\
& Kontrol & 17 & 15.00 & 255.00 & & \\
\hline
\end{tabular}

Tablo 3'te görüldügü gibi deney ve kontrol gruplarına atanan ebeveynlere uygulanan 'ADÖ' ve 'ERKA Ölçeği' Rol Doyumu alt ölçeklerinden elde edilen öntest puanları arasında anlamlı bir farklılık olmadı̆̆ ortaya çıkmıştır.

\subsection{Veri Toplama Araçları}

Araştırmada öğrencilere 'Saldırganlık Ölçeği'; ebeveynlere ise 'Aile Değerlendirme Ölçeği', 'Anne-baba Stres Ölçeği' ve 'Ebeveyn Rolüne İlişkin Kendilik Algısı Ölçeği', uygulanmıştır.

\subsection{Saldırganlık Ölçegi (SÖ)}

Bu araştırmada, 1992 yılında Buss ve Perry (1992) tarafından geliştirilen, Buss ve Warren (2000) tarafından güncellenen 'Aggression Questionnaire' adlı ölçeğin, Can (2002) tarafından Türkçeye uyarlanmış biçimi olan 'Saldırganlık Ölçeği' kullanılmıştır. 34 maddeden oluşan ölçeğin; fiziksel saldırganlık (8 madde), sözel saldırganlık (5 madde), öfke ( 8 madde), düşmanlık (7 madde), dolaylı saldırganlık (6 madde) bölümlerinden oluşan 5 alt ölçeği bulunmaktadır. Ölçek 5'li likert tipi olup yanıtlama seçenekleri " $5=$ =karakterime tamamen uygun", "4=karakterime çok uygun", " $3=$ Karakterime biraz uygun", " $2=$ Karakterime çok az uygun", " $1=$ karakterime hiç uygun değil" şeklindedir. Ölçekten alınabilecek en düşük puan 34 en yüksek puan 170'dir. Saldırganlık ölçeği toplam puanı yüksek ise, bireyin alt ölçek puanlarını incelemek gerekir. Ölçekten alınan puanlardan 58 ve aşağısı düşük, 59 ve 110 arası orta, 111 ve üzeri yüksek saldırganlık düzeyine işaret etmektedir (Can, 2002; Buss, Warren, 2000). Güvenirliğin incelenmesinde, Cronbach Alfa iç tutarlık katsayısı ölçeğin tamamı için $\mathrm{r}=.91$ olarak bulunmuştur. Bir hafta arayla ölçek tekrar uygulanmış, test tekrar test korelasyonu, toplam puanda $r=.85$ olarak yüksek düzeyde anlamlı bulunmuştur. Geçerlik çalışmasında benzer ölçekler geçerliği yöntemi kullanılmıştır. Benzer ölçekler geçerliğini sınamak için, Spielberger tarafindan geliştirilen Sürekli ÖfkeÖfke Tarz Ölçeği kullanılmıştır. Öfke kontrolü ile Saldırganlık Ölçeği toplam saldırganlık puanları arasında $r=-0.30$ negatif düzeyde anlamlı bir korelasyon bulunmuştur.

\subsection{Ebeveyn Rolüne İlişkin Kendilik Algısı Ölçeği (ERKA)}

Mac Phee, Benson ve Bullock (1986), tarafindan geliştirilmiş Güler ve Yetim (2008), tarafindan Türkçe uyarlaması yapılmıştır. Ölçek ebeveyn bilişlerini belirlemeye yönelik geliştirilen ve bireyin kendisi hakkında bilgi vermesi esasına dayalı olan bir ölçme aracıdır. Ölçek, yeterlilik (6 madde), rol doyumu (6 madde), yatırım (5 madde) ve rol dengelemesi (5 madde) alt ölçeklerinde toplam 22 maddeden oluşmaktadır. Her bir maddenin dört cevabı 1, 2, 4, 5 olarak puanlanmaktadır. Ölçekten alınacak tek bir toplam puan yoktur. Her bir alt boyut için ise, söz konusu boyutu temsil eden maddelerin toplamı alınmaktadır. Alınan yüksek puan, o boyutta bireyin ebeveyn rolüne ilişkin kendilik algısını olumlu değerlendirdiğini göstermektedir. Ölçeğin orijinal geçerlik çalışmasında maddelerin ölçmeyi amaçladığı faktörler altında yer aldığı görülmektedir. Rol doyumuna ait maddeler varyansın 
$\%$ 27.1'ini, yeterlilik boyutuna ait maddeler, \% 11.6'sın1, yatırım boyutuna ait maddeler $\%$ 8.2'sini ve rol dengeleme boyutuna ait maddeler \% 6.8'ini açıklamaktadır. Alt ölçeklerin Cronbach alfa iç tutarlık katsayılarına bakıldığında rol doyumu için .80 , yeterlilik için .78, rol dengelemesi için .76 ve yatırım için .72 arasında olduğu gözlenmiştir. Test-tekrar test Cronbach alfa katsayıları sırasıyla; rol doyumu için .88, yeterlilik için .86, rol dengelemesi için .92 ve yatırım için .82'dir. Ölçeğin ölçüt geçerlik çalışması Messer ve Harter (1985) tarafından geliştirilen "Ben Nasılım" (What I am Like, WIAL) ölçeği ile yapılmış ve yeterlilik ve rol doyumu alt ölçekleri ile WIAL ölçeğinin yeterli bakım veren alt ölçeği arasında sırasıyla $.53, .25$; aynı ölçeğin genel benlik değeri alt ölçeği arasında sırasıyla .62, .36 düzeyinde anlamlı olan ilişkiler bulunmuştur.

\subsection{Anne-Baba Stres Ölçeği (ABSÖ)}

Anne-Baba Stres Düzeyi Ölçeği (ABSÖ) anne babaların günlük yaşamda çocukları ile ilişkilerinde yaşadıkları stresi ölçmeye yönelik bir araç olarak Özmen ve Özmen (2012) tarafından geliştirilmiştir. ABSÖ’nün geçerlik çalışmaları kapsamında yapı geçerliği incelenmiştir. Açımlayıcı faktör analizi sonucunda varyansın \%32.20'sini açıklayan, 16 maddeden oluşan tek boyutlu bir ölçek elde edilmiştir. ABSÖ’ nün içtutarlılık güvenirliği için hesaplanan Cronbach Alfa değeri .85 ve Spearman Brown İkiyarı test güvenirliği .82 olarak hesaplanmıştır. Ölçekte yer alan tüm maddeler için madde toplam korelasyonları ise .34 ile .58 arasında değişmektedir. Madde analizi kapsamında elde edilen t değerlerinin anlamlı olduğu $(\mathrm{p}<.001)$ görülmüştür. Sonuç olarak, Anne Baba Stres Ölçeği (ABSÖ), 16 maddeden oluşan tek boyutlu bir ölçektir. Ölçekte dörtlü Likert tipi bir derecelendirme (Her zaman=4, Sık sık=3, Bazen=2, Hiçbir zaman=1) kullanılmıştır. Ölçekten alınabilecek en düşük puan 16, en yüksek puan 64'tür. Ölçekten alınan yüksek puan, anne baba stresinin yükssek olduğunu göstermektedir.

\subsection{Aile Değerlendirme Ölçeği (ADÖ)}

Aile Değerlendirme Ölçeği (McMaster Family Assesment Device) ABD'de Brown Üniversitesi ve Butler Hastanesi tarafından Aile Araştırma Programı çerçevesinde Epstein, Baldwin ve Bishop (1983) tarafindan aile işlevlerini çeşitli boyutlarda ölçmek üzere geliştirilmiştir. Ölçeğin ülkemize uyarlama çalışması Bulut (1990) tarafından yapılmıştır. On iki yaş üzerindeki tüm aile üyelerine ve deneğin kendisine aile işlevlerini değerlendirmek amaciyla uygulanabilmektedir. Problem Çözme (PRÇ), İletişim (ILT), Roller (ROL), Duygusal Tepki Verebilme (DTV), Gereken İlgiyi Gösterme (GİG), Davranış Kontrolü (DVK) ve Genel Fonksiyonlar (GNF) adı altında 7 alt ölçekten oluşan Aile Değerlendirme Ölçeği 60 maddedir. Ölçek "Aynen katılıyorum" (1 puan) ile "Hiç katılmıyorum" (4 puan) arasında değiş̧en dört seçenek üzerinden puanlanmaktadır. Ölçekte "1" puan sağlıklı, "4" puan sağlıksız cevabının göstergesidir, 35 madde tersine çevrilmiş maddedir. Yüksek puan o işlev açısından sağlıksızlığın arttığını gösterir. Alt ölçeklerin Cronbach Alfa katsayıları .38 ile .86 arasında değişmektedir.

\subsection{Deneme Uygulamasi}

Ergenlere yönelik 'Şiddet ve Saldırganlıkla Baş Etme' programı ve ebeveynlere yönelik 'Şiddetsiz Karşı Koyma' programının içeriğinde yer alan etkinliklerin hedeflenen davranışları kazandıracak nitelikte olup olmadığı ve belirlenen sürenin yeterli olup olmadığını değerlendirebilmek için deneme uygulamaları yapılmıştır. Deneme uygulamaları sırasında her bir etkinliğin ne kadar zaman aldığı hesaplanmış ve hem ebeveyn ve hem de öğrenci grubunda zaman konusunda problem yaşanmadı̆̆ gözlenmiştir. Ebeveyn grubunda bazı etkinliklerde verilen yönergelerin tam anlaşılmadığı görülmüş ve gerekli düzeltmeler araştırmacılar tarafından yapılmıştır. Ayrıca, her bir oturum katılımcıların izni ile video 
kaydına alınmış ve tüm oturumlar izlenerek içerik ve kültüre uygunluk bakımından değerlendirmeler yapılmıştır. Deneme uygulamaları sırasında herhangi bir ölçüm yapılmamıştır.

\subsection{Deneysel İşlem}

Ergenlere yönelik 'Şiddet ve Saldırganlıkla Baş Etme' programı ve ebeveynlere yönelik 'Şiddetsiz Karşı Koyma' programı deney grupları ile haftada bir kez, yaklaşık 90 dakikalık oturumlar halinde yürütülmüştür. Uygulamalar araştırmacı tarafindan ebeveyn ve ergen gruplarına hafta içi öğlen saatlerinde birbirine paralel zaman dilimlerinde uygulanmıştır. Programın içerdiği etkinliklerin, pilot uygulamalarla benzer sıra ve süre ile uygulanmasına özen gösterilmiştir. Ergen ve Ebeveyn deney gruplarının uygulamaları öğrencilerin kendi okullarında, okul toplantı salonunda, üyelerin çember biçiminde rahatça oturabilecekleri ve etkinliklerin yapılmasına olanak verecek bir ortamda yapılmıştır. Öğrenci oturumlarına 1sınma aktiviteleri ile başlanmış ve süreç sonunda ikramlarda bulunulmuştur. Ebeveyn programının küçük grup aktivitelerini içermesinden dolayı, tüm süreç bir lider uygulayıcı ve bir de yardımcı lider uygulayıcısı ile yürütülmüştür.

\section{9. Şiddet ve Saldırganlıkla Baş Etme Psikoeğitim Programı}

Ergenlere uygulanan grup çalışması, anne-babalara uygulanan 'Şiddetsiz Karşı Koyma' ebeveyn programını destekleyecek şekilde sistemik psikoterapi yaklaşımına dayalı olarak hazırlanmış, öğrencilerin sözel ve fiziksel saldırganlık, düşmanlık, kin ve nefret içeren tutum ve davranışlar yerine, anlaşmazlık durumlarında yaşadıkları gerginlikle yapıcı çatışma çözme, iletişim ve sosyal becerilerini geliştirerek baş etmeleri hedeflenmiştir. Bununla birlikte, yaşanan gerginlik ve öfke durumlarında, öğrencilerin aile içi etkileşimlerinin davranışları üzerindeki etkileri ve kendi davranışlarının aile içi etkileşimleri üzerinde nasıl bir etkisi olduğu ile ilgili döngüsel sorulardan faydalanılarak, göstermiş oldukları davranışlara yönelik farkındalıklarının gelişimi ve bu şekilde gerginlikle baş etme becerilerine katkı sağlanması amaçlanmıştır. Programın hazırlanmasında, daha önce hazırlanmış olan ve değişik araştırmalarda kullanılan eğitim programlarından ve konu ile ilgili diğer kaynaklardan yararlanılmıştır (Gladding, 2012; Akgün \& Araz, 2010; Elizabeth ve Elisabeth, 2010; Yavuzer ve Üre, 2010; Türnüklü, Kaçmaz, İkiz ve Balc1, 2009; McGoldrick, Gerson \& Petry, 2008; Kuzucu, 2007; Schrumpf, Crawford, \& Bodine, 2007; Gümüş, 2006; Uysal, 2006; Corey, 2005; Kulaksızoğlu, 2004; Taştan, 2004; Herrmann ve McWhirter, 2001; Öner, 2000). Şiddet ve saldırganlıkla baş etme psikoeğitim programının içeriğine baktığımızda: her bir ergenin şiddet içerikli davranışı, duygu ve düşünceleri ve yaşantıları grup ortamında ele alınmaktadır. Grup, davranış düzenleyici olarak, olumlu anlamda kullanılmaktadır. Burada ergenler ile süreç odaklı olarak şu konular ele alınmaktadır; 1. Hafta: Tanışma, giriş, saldırganlık, saldırgan davranışlar nedir? 2. Hafta: Çatışma nedir? kaynakları ve etkileri nelerdir? 3. Hafta: Duyguları fark etme ve ifade etme, 4. Hafta: Empati becerileri, 5. Hafta: Etkin dinleme ve iletişim becerileri, 6. Hafta: Aile etkileşimi, genogram ve aile dizimi uygulamaları, 7. Hafta: Öfke yönetimi becerileri, 8. Hafta: Gevşeme egzersizleri, 9. Hafta: Çatışma çözme becerileri, 10. Hafta: Sonlandırma ve süreci değerlendirme.

\subsection{0. Şiddetsiz Karşı Koyma Ebeveyn Programı (Non-Violent Resistance Programme- NVR)}

Araştırma kapsamında şiddet ve saldırganlık davranışları olan öğrencilerin ebeveynlerinden oluşan deney grubuna, 14 oturumluk Şiddetsiz Karşı Koyma (NVR) ebeveyn programı (Elizabeth ve Elizabeth, 2010) uygulanmıştır. Programın ana hatları incelendiğinde bireysel ebeveyn görüşmeleri, on oturumluk beceri eğitimleri (1. Gerginlik artı̧̧1, 2. Evde ebeveynin 
varlı̆̆1, 3. Sepetler, 4. Destekleyiciler ve destek sistemleri, 5. Duyurma tekniği, 6. Ebeveyn değerleri, duyuru, mutabakat hareketleri, 7. Aktif direnç/karşı koyma, 8. Oturma eylemi, 9. Ev dışında ebeveynin varlığ 1,10 . Özet ve sertifikalandırma) ve destekleyici üç oturumdan (1: Duyuru/Ilan Etme, 2.Oturma eylemi, 3.Kendi kendine bakım) oluşmaktadır. 10 oturumluk ana NVR programı ve üç oturumluk destekleyici oturumlara ek olarak ebeveynlerin aile etkileşim ağının bireylerin tutum ve davranışlarına etkisi ve bireysel tutum ve davranışların aile yapısı ve etkileşimleri üzerindeki etkilerini fark etmek amacıyla 'Aile Soy Ağacı (Genogram)' ve 'Aile Dizimi' tekniklerini içeren ek bir oturum yapılmıştır. Ebeveynlere, programdaki grup çalışmaları sürecinde telefonla destek, rol oynama, video izleme teknikleri ve NVR programına ek olarak ihtiyaç durumunda ev ziyaretleri uygulanmıştır.

NVR ebeveyn eğitimi, çocuklarının şiddet, kendine zarar verebilecek aktiviteler, okuldan kaçma ve diğer akut disiplin problemleri ile baş etmeye yardım etmek amacıyla anne-babalar için tasarlanmıştır (Omer, 2004, 2011). Temelde, NVR şiddetsiz bir biçimde baskı ve şiddete karş1 koymak için sosyo-politik bir strateji olarak geliştirilmiş̧ir (Lavi-Levavi, Shachar, Omer, 2013). NVR'nin hedefi, öncelikle çaresiz ve çocuklarıyla ilgili gerginliğe kapılan ebeveynlere yardım etmek, geri kışkırtma ya da pes etmeksizin çocuğun saldırgan ve kendine zarar verici davranışlarına etkili bir şekilde karşı koymayı öğrenerek ebeveynliklerini geri kazandırmaktır. Müdahale programları, ebeveynlerle yürütülmesine rağmen, temel bakış açısı hem ebeveynler hem de çocuk üzerine yoğunlaşır. NVR' nin ebeveynlere çocuk için güven verici bir işlev oluşturmalarına olanak sağlayan güvenli ve istikrarlı bir ilişki çerçevesi inşa etmelerine yardım ettiği varsayılır (Omer, Steinmetz, Carthy ve Schlippe, 2013).

\subsection{Verilerin Analizi}

$\mathrm{Bu}$ araştırmada deney öncesi ve deney sonrasında toplanan veriler, öncelikle dijital ortama aktarılmış; ardından SPSS 17 paket programı kullanılarak analiz edilmiştir. Çözümleme sürecinde kullanılan istatistiksel analiz yönteminin varsayımları arasında olan normallik ve diğer sayıltıları karşılayan ölçümler için 'Karışık Ölçümler İçin İki faktörlü Anova', Tekrarlı Ölçümler İçin Tek Yönlü Anova ve İlişkisiz Gruplar İçin t testi kullanılmıştır. Normallik sayıltısının sağlanamadığı durumlarda ise parametrik olmayan testlerden Wilcoxon İşaretli Sıralar Testi ve Mann Whitney U testi kullanılmıştır. İzleme ölçümü ise sontest ölçümlerinin bitiminden iki ay sonra deney ve kontrol grubunda bulunan öğrenci ve ebeveynlerden alınmıştır.

\section{Bulgular}

$\mathrm{Bu}$ bölümde denencelerin test edilmesi amaciyla yapılan istatistiksel analizler sonucunda elde edilen bulgular yer almaktadır. Araştırmadan elde edilen bulgular denence sırasına uygun olarak aşağıda sunulmuştur.

4.1. Denence 1: Araştırmanın ilk denencesi 'Şiddet ve saldırganlıkla baş etme programının uygulandı ̆̆ deney grubu ögrencilerinin, kontrol grubu ögrencilerine göre 'Saldirganlık Ölçeği'nden aldıklarl sontest puanları öntest puanlarından anlaml düzeyde düşüktür ve bu fark kalıcıdır.' şeklinde ifade edilmiştir.

Deney ve kontrol grubunun saldırganlık ölçeğinden aldıkları öntest, sontest ve izleme testi puan ortalamaları arasında farklılıkların anlamlı olup olmadığı 'Karışık Ölçümler İçin İki faktörlü Anova' istatistiksel analiz tekniği ile incelenmiş ve elde edilen bulgular aşağıda sunulmuştur. 
Tablo 4.Deney ve Kontrol Grubundaki Öğrencilerin Saldırganlık Ölçeği Öntest Sontest İzleme Puanlarına İlişkin Uygulanan İki Faktörlü Anova Sonuçları

\begin{tabular}{llllll}
\hline Varyansın Kaynă̆ı & KT & Sd & KO & F & p \\
\hline Denekleraras1 & 40139,333 & 33 & & & \\
Grup (Deney/Kontrol) & 27342,157 & 1 & 27342,157 & 68,370 &, 000 \\
Hata & 12797,176 & 32 & 399,912 & & \\
& 29966.666 & 66 & & & \\
Denekleriçi & 11607,235 & 2 & 5803,618 & 37,276 &, 000 \\
Ölçüm (Öntest-sontest-izleme) & $\mathbf{8 3 9 5 , 0 7 8}$ & $\mathbf{2}$ & $\mathbf{4 1 9 7 , 5 3 9}$ & $\mathbf{2 6 , 9 6 0}$ & $\mathbf{0 0 0}$ \\
Grup* Ölçüm & 9964,353 & 64 & & & \\
Hata & 70105.999 & 99 & & & \\
Toplam & & & & &
\end{tabular}

Karışık Ölçümler İçin İki faktörlü Anova analizi sonuçlarına göre Saldırganlık Ölçeği (SÖ) puanlarının deney öncesinden sonrasına farklılık gösterdiği, yani farklı işlem gruplarında olmak ile tekrarlı ölçümler faktörlerinin öğrencilerin saldırganlık ölçeği puanları üzerindeki ortak etkilerinin anlamlı olduğu bulunmuştur $(F(2-64)=26,96, p<.001)$. Bu bulgu deney ve kontrol grubunda olmanın, öğrencilerin saldırganlık ölçeği puanlarını düşürmede farklı etkilere sahip olduğunu göstermektedir. Bunun yanı sıra deney ve kontrol gruplarının saldırganlık ölçeğinden almış oldukları öntest-sontest ve izleme puanları arasında da anlamlı bir fark olduğu görülmektedir $(\mathrm{F}(2-66)=37,27, \mathrm{p}<.001)$. Aynı şekilde, grup ana etkisinin anlamlı düzeyde olduğu saptanmıştır $(\mathrm{F}(1-32)=68,37, \mathrm{p}<.001)$. Bu bulgulara göre, deney ve kontrol grubundaki öğrencilerin saldırganlık puanları, uygulanan programa bağlı olarak farkl11ık göstermektedir.

Deneysel işleme tabi tutulan öğrencilerin SÖ öntest puanlarına $(X=119,70)$ göre, sontest $(\mathrm{X}=88,52)$ puanlarında istatistiksel açıdan anlamlı bir düşüş olması ve izleme testlerinde $(\mathrm{X}=72,64)$ de bu düşüşün devam etmesi, bununla birlikte hiçbir deneysel işlem uygulanmayan kontrol grubunun SÖ öntest $(X=127,23)$ ve sontest $(X=126,94)$ ve izleme $(\mathrm{X}=124,94)$ puanlarında anlamlı bir farklılık olmaması bulgusuna dayanarak, uygulanan "Şiddet ve Saldırganlıkla Baş Etme" programının öğrencilerin saldırganlık düzeylerini azaltmada etkili olduğu söylenebilir.

Deney grubunun Saldırganlık Ölçeği sontest ve izleme puanlarında gözlemlenen farkın kalıcı olup olmadığını incelemek için, Saldırganlık Ölçeğinin tekrarlı ölçümlerinden aldıkları puanlar arasındaki farka, Tekrarlı Ölçümler İçin Tek Yönlü Anova ile bakılmıştır. Varyans analizi sonucuna göre deney grubuna katılan ergenlerin puanları arasında istatistiksel açıdan anlamlı bir fark bulunmuştur $(\mathrm{F}=75.085 ; \mathrm{p}<.001)$. Ölçümler arasındaki bu farkın kaynağına Bonferroni testi ile bakılmış ve sonuçlar Tablo 5 'te sunulmuştur. 
Tablo 5.Deney ve Kontrol Gruplarının Saldırganlık Ölçeği Öntest Sontest ve İzleme Testi Puan Ortalamalarına İlişkin Karşılaştırma Testi (Bonferroni) Sonuçları

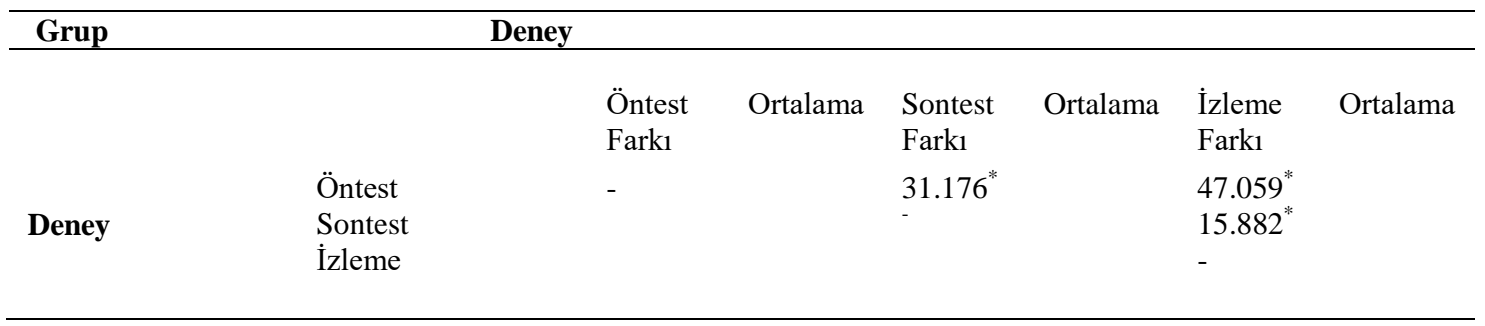

Bonferroni testi $* \mathrm{p}<.001$

Tablo 5'te görüldüğ̈ gibi deney grubu öğrencilerinin öntest $(X=119,70)$ puan ortalamaları ile sontest $(\mathrm{X}=88,52)$ ve izleme $(\mathrm{X}=72,64)$ testi puan ortalamaları arasında anlamlı bir fark olduğu ve bununla birlikte yine sontest $(X=88,52)$ puan ortalamaları ile izleme $(X=72,64)$ testi puan ortalamaları arasında da anlamlı bir farklılık olduğu görülmüştür. Sonuç olarak, öğrencilerin saldırganlık ölçeği izleme testi puanlarındaki düşüşün devam etmesi 'Şiddet ve Saldırganlıkla Baş Etme Programı'nın uzun süreli etkisinin bir göstergesi olabilir.

4.2. Denence 2: Şiddetsiz karşı koyma programının uygulandığı deney grubu ebeveynlerinin kontrol grubu ebeveynlerine göre 'Ebeveynlik Rolüne İlişkin Kendilik Algısı Ölçeği, Rol Doyumu, Yeterlik, Yatırım ve Rol Dengeleme Alt Boyutlarından aldıkları sontest puanları öntest puanlarından anlamlı düzeyde yüksektir ve bu fark kalıcıdır.

Deney ve kontrol grubunda bulunan anne-babaların Ebeveyn Rolüne İlişkin Kendilik Algısı Ölçeği (ERKA) alt ölçeklerinden aldıkları öntest, sontest ve izleme testi puan ortalamaları arasında farklılıklar olduğu görülmüştür. Puan ortalamaları arasındaki farkların anlamlı olup olmadığı Wilcoxon İşaretli Sıralar Testi ile incelenmiş ve elde edilen bulgular aşağıda sunulmuştur.

Araştırmanın ikinci denencesini sınamaya yönelik verilerin analizi aşamasında, grupların söz konusu ölçme aracından aldıkları puanların normal dağılım özelliği göstermemesi sebebiyle, parametrik olmayan testlerden biri olan Wilcoxon İşaretli Sıralar Testi uygulanarak deney ve kontrol grubundaki ebeveynlerin öntest ve sontest puanları arasında anlamlı bir farklılık olup olmadığına bakılmıştır. Analiz sürecinde deney ve kontrol grubuna ait veriler ayrı ayrı analiz edilmiş, elde edilen bulgular Tablo 6'da sunulmuştur.

Tablo 6.Deney ve Kontrol Grubundaki Anne-Babaların Ebeveynlik Rolüne İlişskin Kendilik Algısı Ölçeği Rol Doyumu Alt Boyutu Öntest ve Sontest Puanlarına İlişkin Wilcoxon İşaretli Sıralar Testi Analiz Sonuçları

\begin{tabular}{lllllll}
\hline Gruplar & Sontest-Öntest & n & Sıra Ortalamaları & Sıra Toplamı & Z & p \\
\hline \multirow{3}{*}{ Deney Grubu } & Negatif Sıra & 7 & 5,57 & 39,00 & $-1,207$ &, 227 \\
& Pozitif Sıra & 8 & 10,13 & 81,00 & & \\
& Eşit & 2 & & & & \\
\multirow{2}{*}{ Kontrol Grubu } & Negatif Sıra & 6 & 7,83 & 47,00 &,- 740 &, 459 \\
& Pozitif Sıra & 9 & 8,11 & 73,00 & & \\
& Eşit & 2 & & & & \\
\hline
\end{tabular}


Tablo 6 incelendiğinde deney ve kontrol grubundaki anne-babaların ERKA Ölçeği Rol Doyumu Alt Boyutu öntest ve sontest puanları bakımından anlamlı bir farklılık gösterip göstermediğine ilişkin yapılan Wilcoxon İşaretli Sıralar Testi sonuçlarına göre, deney grubundaki anne-babaların öntest ve sontest puanları arasında anlamlı bir farklılık olmadığı ( $\mathrm{Z}=-1.207 ; \mathrm{p}>.05)$ görülmüştür. Benzer şekilde herhangi bir işlemin uygulanmadığı kontrol grubundaki anne-babaların da öntest ve sontest puanları arasında da anlamlı bir farklıl1k olmadığg $(Z=-, 740 ; \mathrm{p}>.05)$ görülmüştür.

Buna göre, deney grubundaki anne-babaların Rol Doyumu alt boyutu öntest ve sontest puanları bakımından anlamlı bir farklılık göstermemesine bakılarak, uygulanan 'Şiddetsiz Karşı Koyma' ebeveyn programı'nın deney grubunda bulunan anne-babaların Rol Doyumu algılarında önemli bir etkisinin olmadığ 1 söylenebilir. Deney grubundaki anne-babaların ERKA Ölçeği Rol Doyumu alt boyutu öntest sontest ölçümlerinden aldıkları puanlar arasında anlamlı bir farklılık olmadığından sontest izleme testi puan farkına bakılmasına gerek görülmemiştir.

Deney ve kontrol grubundaki anne-babaların ERKA Ölçeği Yeterlik alt boyutu öntest ve sontest ölçümlerinden aldıkları puanlar arasındaki farklılı̆̆ s sınamak amacıyla yapılan Wilcoxon İşaretli Sıralar Testi analizinden elde edilen sonuçlar Tablo 7' de yer almaktadır.

Tablo 7. Deney ve Kontrol Grubundaki Anne-Babaların Ebeveynlik Rolüne İlişskin Kendilik Algısı Ölçeği Yeterlik Alt Boyutu Öntest ve Sontest Puanlarına İlişkin Wilcoxon İşaretli Sıralar Testi Analiz Sonuçları

\begin{tabular}{lllllll}
\hline Gruplar & Sontest-Öntest & $\mathbf{n}$ & Sıra Ortalamaları & Sıra Toplamı & Z & p \\
\hline \multirow{2}{*}{ Deney Grubu } & Negatif Sıra & 5 & 6,10 & 30,50 & $-2,185$ &, 029 \\
& Pozitif Sıra & 12 & 10,21 & 122,50 & & \\
& Eşit & 0 & & 28,50 & $-1,197$ &, 231 \\
\multirow{2}{*}{ Kontrol Grubu } & Negatif Sıra & $4^{\mathrm{a}}$ & 7,13 & 62,50 & \\
& Pozitif Sıra & $9^{\mathrm{b}}$ & 6,94 & & \\
& Eşit & $4^{\mathrm{c}}$ & & &
\end{tabular}

Tablo 7 incelendiğinde deney grubundaki anne-babaların öntest ve sontest puanları arasında anlamlı bir farklılığın olduğu $(Z=-2,185 ; \mathrm{p}<.05)$, herhangi bir işlemin uygulanmadığı kontrol grubundaki anne-babaların öntest ve sontest puanları arasında ise anlamlı bir farklılık olmadığ1 $(Z=-1,197 ; p>$.05) görülmüştür. Bu sonuç ile deney grubundaki anne-babaların yeterlik alt boyutu öntest puanlarının sontest puanlarında artış göstermesi dikkate alındığında uygulanan 'Şiddetsiz Karşı Koyma Programı'nın anne-babaların kendi ebeveynlik becerileri yeterliğine ilişkin algılamalarında önemli bir etkisinin olduğu söylenebilir.

Deney grubundaki anne-babaların ERKA Ölçeği Yeterlik alt boyutu sontest ve izleme testi ölçümlerinden aldıkları puanlar arasındaki farklılığı sınamak amacıyla yapılan Wilcoxon İşaretli Sıralar Testi analizinden elde edilen sonuçlar Tablo 8' de yer almaktadır.

Tablo 8. Deney Grubundaki Anne-Babaların ERKA Ölçeği Yeterlik Alt Boyutu Sontest ve İzleme Testi Puanlarına İlişkin Wilcoxon İşaretli Sıralar Testi Analiz Sonuçları

\begin{tabular}{llllll}
\hline Sontest-Öntest & $\mathbf{n}$ & Sıra Ortalamaları & Sıra Toplamı & Z & $\mathbf{p}$ \\
\hline Negatif Sıra & 7 & 11,50 & 80,50 & & \\
Pozitif Sıra & 10 & 7,25 & 72,50 &,- 190 &, 849 \\
Eşit & 0 & & & & \\
\hline
\end{tabular}


Tablo 8 incelendiğinde deney grubuna katılan anne babaların ERKA Ölçeği Yeterlik Alt Boyutu sontest ve izleme testi puanları arasında anlamlı bir farklılık olmadığı $(Z=-, 190 ; p>$ .05) görülmektedir. Elde edilen bulgulara göre araştırmanın ikinci denencesi doğrulanmış, yani kabul edilmiştir.

Deney ve kontrol grubundaki anne-babaların ERKA Ölçeği Yatırım alt boyutu öntest ve sontest ölçümlerinden aldıkları puanlar arasındaki farklılığı sınamak amacıyla yapılan Wilcoxon İşaretli Sıralar Testi analizinden elde edilen sonuçlar Tablo 9' da yer almaktadır.

Tablo 9. Deney ve Kontrol Grubundaki Anne-Babaların Ebeveynlik Rolüne İlişkin Kendilik Algııı Ölçeği Yatırım Alt Boyutu Öntest ve Sontest Puanlarına İlişsin Wilcoxon İşaretli Sıralar Testi Analiz Sonuçları

\begin{tabular}{|c|c|c|c|c|c|c|}
\hline Gruplar & Sontest-Öntest & $\mathbf{n}$ & Sıra Ortalamaları & Sıra Toplamı & $\mathbf{Z}$ & $\mathbf{P}$ \\
\hline \multirow[b]{2}{*}{ Deney Grubu } & Negatif Sıra & 10 & 7,90 & 79,00 & \multirow[b]{2}{*}{$-1,677$} & \multirow[b]{2}{*}{,094 } \\
\hline & Pozitif Sıra & 4 & 6,50 & 26,00 & & \\
\hline \multirow{3}{*}{ Kontrol Grubu } & $\begin{array}{l}\text { Eşit } \\
\text { Negatif Sıra }\end{array}$ & $\begin{array}{l}3 \\
9\end{array}$ & \multirow[t]{3}{*}{9,33} & 84,00 & \multirow{3}{*}{,- 357} & \multirow{3}{*}{, 721} \\
\hline & Pozitif Sıra & 8 & & 69,00 & & \\
\hline & Eşit & 0 & & & & \\
\hline
\end{tabular}

Tablo 9 incelendiğinde deney ve kontrol grubundaki anne-babaların ERKA Ölçeği Yatırım Alt Boyutu öntest ve sontest puanları bakımından anlamlı bir farklılık gösterip göstermediğine ilişkin yapılan Wilcoxon İşaretli Sıralar Testi sonuçlarına göre, deney grubundaki anne-babaların öntest ve sontest puanları arasında anlamlı bir farklılığın olmadığ1 $(Z=-1,677 ; \quad p>\quad .05)$ görülmüştür. Benzer şekilde herhangi bir işlemin uygulanmadığ1 kontrol grubundaki anne-babaların öntest ve sontest puanları arasında da anlamlı bir farklılığın olmadığı $(Z=-, 357 ; p>.05)$ görülmüştür. Sonuç olarak elde edilen bulgulara göre araştırmanın dokuzuncu denencesi doğrulanmamıştır.

Deney grubundaki anne-babaların ERKA Ölçeği Yatırım alt boyutu öntest sontest ölçümlerinden aldıkları puanlar arasında anlamlı bir farklılık olmadığından deney ve kontrol grubu katılımcılarının sontest ve izleme testi puan ortalamaları arasındaki farka bakılmasına gerek görülmemiştir.

Deney ve kontrol grubundaki anne-babaların ERKA Ölçeği Rol Dengeleme alt boyutu öntest ve sontest ölçümlerinden aldıkları puanlar arasındaki farklılığı sınamak amacıyla yapılan Wilcoxon İşaretli Sıralar Testi analizinden elde edilen sonuçlar Tablo 10' da yer almaktadır.

Tablo 10. Deney ve Kontrol Grubundaki Anne-Babaların Ebeveynlik Rolüne İlişkin Kendilik Algısı Ölçeği Rol Dengeleme Alt Boyutu Öntest ve Sontest Puanlarına İlişkin Wilcoxon İşaretli Sıralar Testi Analiz Sonuçları

\begin{tabular}{lllllll}
\hline Gruplar & Sontest-Öntest & n & Sıra Ortalamaları & Sıra Toplamı & Z & p \\
& Negatif Sıra & 2 & 3,00 & 6,00 & & \\
Deney Grubu & Pozitif Sıra & 14 & 9,29 & 130,00 & $-3,211$ &, 001 \\
& Eşit & 1 & & & & \\
& Negatif Sıra & 8 & 9,19 & 73,50 & &, 887 \\
Kontrol Grubu & Pozitif Sıra & 9 & 8,83 & 79,50 &,- 143 & \\
& Eşit & 0 & & & & \\
\hline
\end{tabular}

Tablo 10 incelendiğinde deney grubundaki anne-babaların öntest ve sontest puanları arasında anlamlı bir farklılığın olduğu $(\mathrm{Z}=-3,211 ; \mathrm{p}<.05)$ kontrol grubundaki anne-babaların ise 
öntest ve sontest puanları arasında anlamlı bir farklılı̆̆ın olmadığı $(Z=-, 143 ; p>.05)$ görülmüştür. Bu sonuca göre uygulanan 'Şiddetsiz Karşı Koyma Ebeveyn Programı'nın anne-babaların rol dengelemeye ilişkin algılamalarının artmasında önemli bir etkisinin olduğu söylenebilir.

Deney grubundaki anne-babaların ERKA Ölçeği Rol Dengeleme alt boyutu sontest ve izleme testi ölçümlerinden aldıkları puanlar arasındaki farklılığı sınamak amacıyla yapılan Wilcoxon İşaretli sıralar Testi analizinden elde edilen sonuçlar Tablo 11' de yer almaktadır.

Tablo 11.Deney Grubundaki Anne-Babaların ERKA Ölçeği Rol Dengeleme Alt Boyutu Sontest ve İzleme Testi Puanlarına İlişkin Wilcoxon İşaretli Sıralar Testi Analiz Sonuçları

\begin{tabular}{llllll}
\hline Sontest-Öntest & n & Sıra Ortalamaları & Sıra Toplamı & Z & p \\
\hline Negatif Sıra & 9 & 8,50 & 76,50 & & \multirow{2}{*}{, 347} \\
Pozitif Sıra & 6 & 7,25 & 43,50 & \\
Eşit & 2 & & & & \\
\hline
\end{tabular}

Tablo 11 incelendiğinde deney grubu katılımcılarının sontest ve izleme testi puan ortalamaları arasında anlamlı bir farklılı̆̆ın olmadığ $1(Z=, 940 ; \mathrm{p}>.05)$ görülmektedir.

4.3. Denence 3: Araştırmanın üçüncü denencesi 'Şiddetsiz karşı koyma programının uygulandı̆̆ deney grubu ebeveynlerinin kontrol grubu ebeveynlerine göre 'Aile Değerlendirme Ölçeği'nden aldıkları sontest toplam puanları öntest puanlarından anlaml düzeyde düşüktür ve bu fark kalıcıdır' şeklinde ifade edilmiştir.

Deney ve kontrol grubunda bulunan öğrencilerin 'Aile Değerlendirme Ölçeği'nden aldıkları öntest, sontest ve izleme testi puan ortalamaları arasında farklılıklar olduğu görülmüsstür. Araştırmanın üçüncü denencesini sınamaya yönelik verilerin analizi aşamasında, grupların söz konusu ölçme aracından aldıkları puanların normal dağılım özelliği göstermemesi sebebiyle, parametrik olmayan testlerden biri olan Wilcoxon İşaretli Siralar Testi uygulanarak deney ve kontrol grubundaki anne-babaların öntest ve sontest puanları arasında anlamlı bir farklılık olup olmadığına bakılmıştır. Analiz sürecinde deney ve kontrol grubuna ait veriler ayrı ayrı analiz edilmiş, elde edilen bulgular Tablo 12' de verilmiştir.

Tablo 12. Deney ve Kontrol Grubundaki Anne-Babaların Aile Değerlendirme Ölçeği Öntest ve Sontest Puanlarına İlişkin Wilcoxon İşaretli Sıralar Testi Analiz Sonuçları

\begin{tabular}{lllllll}
\hline Gruplar & Sontest-Öntest & $\mathbf{n}$ & Sıra Ortalamaları & Sıra Toplamı & Z & p \\
\hline \multirow{3}{*}{ Deney Grubu } & Negatif Sıra & 17 & 9,00 & 153,00 & &, 000 \\
& Pozitif Sıra & 0 &, 00 &, 00 & $-3,622$ & \\
\multirow{2}{*}{ Kontrol Grubu } & Eşit & 0 & & & & \multirow{2}{*}{, 435} \\
& Negatif Sıra & 7 & 8,57 & 60,00 &,- 781 &, \\
& Pozitif Sıra & 10 & 9,30 & 93,00 & & \\
\hline
\end{tabular}

Tablo 12 incelendiğinde deney grubundaki anne-babaların öntest ve sontest puanları arasında anlamlı bir farklılı̆̆ın olduğu $(Z=-3,622 ; \mathrm{p}<.05)$, kontrol grubundaki anne-babaların öntest ve sontest puanları arasında ise anlamlı bir farklılığın olmadığ $(Z=-, 781 ; p>.05)$ görülmüştür. 
$\mathrm{Bu}$ sonuç ile deney grubundaki anne-babaların aile değerlendirme ölçeği öntest puanlarının sontest puanlarında düşüş göstermesi dikkate alındığında, uygulanan programın annebabaların sağlıklı aile işlevselliği algıları üzerinde önemli bir etkisinin olduğu söylenebilir.

Deney grubundaki anne-babaların 'Aile Değerlendirme Ölçeği' sontest ve izleme testi ölçümlerinden aldıkları puanlar arasındaki farklılığı sınamak amacıyla yapılan Wilcoxon İşaretli Sıralar Testi analizinden elde edilen sonuçlar Tablo 13' te yer almaktadır.

Tablo 13. Deney Grubundaki Anne-Babaların Aile Değerlendirme Ölçeği Sontest ve İzleme Testi Puanlarına İlişkin Wilcoxon İşaretli Sıralar Testi Analiz Sonuçları

\begin{tabular}{llllll}
\hline Sontest-Öntest & n & Sıra Ortalamaları & Sıra Toplamı & Z & p \\
\hline Negatif Sıra & 7 & 7,79 & 54,50 & & \\
Pozitif Sıra & 10 & 9,85 & 98,50 & $-1,042$ &, 297 \\
Eşit & 0 & & & & \\
\hline
\end{tabular}

Tablo 13 incelendiğinde deney grubuna katılan anne babaların Aile Değerlendirme Ölçeği sontest ve izleme testi puanları arasında anlamlı bir farklılık olup olmadığını belirlemek için yapılan Wilcoxon İşaretli Sıralar Testi sonuçlarına göre, sontest ve izleme testi puanları arasında anlamlı bir farklılığın olmadığ $1(Z=-1,042 ; p>.05)$ görülmektedir. Elde edilen bu bulgular, araştırmanın üçüncü denencesini destekler nitelikte olup, söz konusu denence doğrulanmıştır.

4.4. Denence 4: Araştırmanın dördüncü denencesi "Şiddetsiz karşı koyma programının uygulandığ deney grubu ebeveynlerinin kontrol grubu ebeveynlerine göre 'Anne-Baba Stres Düzeyi Ölçeği'nden aldlklarl sontest puanları öntest puanlarından anlamlı düzeyde düşüktür ve bu fark kalıcıdır." şeklinde ifade edilmiştir.

Araştırmanın dördüncü denencesini sınamaya yönelik verilerin analizi aşamasında, grupların söz konusu ölçme aracından aldıkları puanların normal dağılım özelliği göstermemesi sebebiyle, parametrik olmayan testlerden biri olan Wilcoxon İşaretli Siralar Testi uygulanarak deney ve kontrol grubundaki anne-babaların öntest ve sontest puanları arasında anlamlı bir farklılık olup olmadığına bakılmıştır. Analiz sürecinde deney ve kontrol grubuna ait veriler ayrı ayrı analiz edilmiş, elde edilen bulgular Tablo 14'te verilmiştir.

Tablo 14. Deney ve Kontrol Grubundaki Anne-Babaların Stres Düzeyi Ölçeği Öntest ve Sontest Puanlarına İlişkin Wilcoxon İşaretli Sıralar Testi Analiz Sonuçları

\begin{tabular}{lllllll}
\hline Gruplar & Sontest-Öntest & $\mathbf{n}$ & Sıra Ortalamaları & Sıra Toplamı & Z & p \\
\hline \multirow{2}{*}{ Deney Grubu } & Negatif Sıra & 16 & 8,50 & 136,00 & & \\
& Pozitif Sıra & 0 &, 00 &, 00 & $-3,517$ &, 000 \\
& Eşit & 1 & & & \\
\multirow{3}{*}{ Kontrol Grubu } & Negatif Sıra & 10 & 10,35 & 103,50 & & \\
& Pozitif Sıra & 6 & 5,42 & 32,50 & $-1,838$ &, 066 \\
& Eşit & 1 & & & & \\
\hline
\end{tabular}

Tablo 14 incelendiğinde deney grubundaki anne-babaların öntest ve sontest puanları arasında anlamlı bir farklılığın olduğu $(Z=-3,517 ; \mathrm{p}<.05)$, herhangi bir işlemin uygulanmadığ kontrol grubundaki anne-babaların öntest ve sontest puanları arasında ise anlamlı bir farklılığın olmadığı $(\mathrm{Z}=-1,838 ; \mathrm{p}>.05)$ görülmüştür. 
$\mathrm{Bu}$ sonuç ile deney grubundaki anne-babaların stres düzeyi ölçeği öntest puanlarının sontestte düşüş göstermesi dikkate alındığında, uygulanan programın anne-babaların stres düzeyleri üzerinde anlamlı bir etkisinin olduğu söylenebilir. Elde edilen bu bulgular, araştırmanın dördüncü denencesini destekler nitelikte olup, söz konusu denence doğrulanmıştır.

Deney grubundaki anne-babaların ABSÖ sontest ve izleme testi ölçümlerinden aldıkları puanlar arasındaki farklılığı sınamak amacıyla yapılan Wilcoxon İşaretli Sıralar Testi analizinden elde edilen sonuçlar Tablo 15 ' te yer almaktadır.

Tablo 15. Deney Grubundaki Anne-Babaların Anne-baba Stres Düzeyi Ölçeği Sontest ve İzleme Testi Puanlarına İlişkin Wilcoxon İşaretli Sıralar Testi Analiz Sonuçları

\begin{tabular}{llllll}
\hline Sontest-İzleme & $\mathbf{n}$ & Sıra Ortalamaları & Sıra Toplamı & $\mathbf{Z}$ & $\mathbf{p}$ \\
\hline Negatif Sıra & 6 & 7,42 & 44,50 & $-1,218$ & \multirow{2}{*}{, 223} \\
Pozitif Sıra & 10 & 9,15 & 91,50 & & \\
Eşit & 1 & & & & \\
\hline
\end{tabular}

Tablo 15 incelendiğinde deney grubuna katılan anne babaların 'Anne-baba Stres Düzeyi Ölçeği' sontest ve izleme testi puanları arasında anlamlı bir farklılığın olmadığı $(Z=-1,218$; $\mathrm{p}>.05)$ görülmektedir.

\section{Tartışma Sonuç ve Öneriler}

Deneysel uygulamalar sonunda elde edilen bulgulara göre araştırmanın birinci denencesi doğrulanmıştır. Sonuç olarak, şiddet ve saldırganlıkla baş etme programına katılmış olan deney grubu öğrencilerinin saldırganlık ölçeği puanlarındaki düşüşün uygulanan beceri eğitim programına bağlı olduğu söylenebilir. Bu etkinin son ölçümden iki ay sonra yapılan izleme testi ölçümünde de devam ettiği görülmüştür.

Eğitim programlarının etkili olmasının en önemli sebeplerinden birinin, uygulanan beceri programının saldırganlığı azaltmaya yönelik içeriğinin yanı sıra aileleri de kapsayan bütüncül bir bakış açısı ile yapılandırılmış olmasından kaynaklandığı düşünülmektedir. Konuyla ilgili literatür incelendiğinde bu araştırmanın sonuçları ülkemizde ve dünyada son dönemde ergenlerle yapılan çeşitli araştırmalarla paralellik göstermektedir (Herrmann ve McWhirter, 2003; Rollin, Ulrey-Kaiser, Potts \& Creason, 2003; Aber, 2003; Williams, Waymouth, Lipman, Mills ve Evans, 2004; Özmen, 2004; Sukhodolsky, Kassinove, Gorman, 2004; Duran ve Eldeleklioğlu, 2005; Smeijsters ve Cleven, 2006; Fong, 2006; Uysal, 2006; Tekinsav-Sütçü, 2006; Ando, Asakura, Ando ve Simons-Morton, 2007; Akdeniz, 2007; Güner, 2007; Horne, Stoddard ve Bell, 2007; Gültekin, 2008; Karataş ve Gökçakan, 2009; Gündoğdu, 2009; Yavuzer ve Üre, 2010; Taner-Derman, 2011; Bedel ve Arı, 2012; Türk, 2013; Bacıŏlu, 2014).

$\mathrm{Bu}$ araştırmada şiddet ve saldırganlık içeren davranışlarla baş etmek için ergenlerin yanı sıra, ebeveynler de bir grup sürecinden geçmişlerdir. İki gruba birden eğitim verilmesi ve grupların paralel bir şekilde yürütülmesinin öğrenci ve ebeveynlerin davranışlarına katkı sağladı̆̆ı, gruplara katılan üyelerle yapılan görüşmelerde de sıklıkla vurgulanmıştır. Buna dayanarak, saldırganlık gibi çok boyutlu bir problemin sadece öğrencilerle yürütülen programlarla ortadan kaldırılmasının çok zor olacağ 1 ve konunun diğer paydaşlarının da işin içine katılmasının bir zorunluluk olduğu düşünülmektedir. Sadece ailenin değil, okul ve okul çevresinin de katılımı ile çoklu müdahaleler daha etkili sonuçların alınmasını sağlamaktadır (McWhirter vd., 2004). 
Ebeveynlere uygulanan program sonrasında elde edilen bulgulara göre ERKA ölçeği yeterlik ve rol dengeleme alt ölçeklerinde anlamlı bir farklılık görülürken; rol doyumu ve yatırım alt ölçeklerinde anlamlı bir fark olmadığı görülmüştür. Sonuç olarak, şiddetsiz karşı koyma programına katılmış olan deney grubu ebeveynlerinin ERKA ölçeği yeterlik ve rol dengeleme algılarına ilişkin alt ölçek puanlarındaki farklılaşmanın uygulanan şiddetsiz karşı koyma ebeveyn beceri programına bağlı olduğu söylenebilir. Yapılan analizler sonucunda yeterlik ve rol dengeleme alt boyutlarında meydana gelen bu etkinin son ölçümden 2 ay sonra yapılan izleme testi ölçümünde de devam ettiği görülmüştür.

Konuyla ilgili literatür incelendiğinde ülkemizde ve dünyada farklı demografik özelliklere sahip ailelere yönelik pek çok farklı aile eğitimi programı uygulandığı görülmektedir. Yapılan çalışmalar hangi eğitim seviyesi ve sosyo-ekonomik düzeyde olursa olsun, ailelerin farkl1 konularda aile eğitimine ihtiyac1 olduğunu göstermiştir. Uygulanan aile ve ebeveyn eğitim programlarının sonunda ebeveynlerin anne-babalık davranışlarının olumlu yönde değiştiği, özyeterlilik duygularının yükseldiği, anne-babalıkla ilgili stres düzeylerinin düştüğü, anne-baba-çocuk/ergen ilişkilerinin olumlu yönde değişim gösterdiği, ebeveyn ve çocuk arasındaki gerginliğin azaldığı, aile etkileşim tarzları ve üyeler arasındaki ilişkilerin farklılaştığı belirlenmiştir (Omer, Schorr-Sapir ve Weinblatt, 2008; Weinblatt ve Omer, 2008; Newman, Fagan ve Webb, 2014; Lav1-Levav1, Shachar ve Omer, 2013; KaymakÖzmen, 2013; Çekiç, 2015).

Araştırma bulgularına bakıldığında, ebeveynlerin yeterlik ve rol dengeleme algılarına ilişkin alt ölçek puanlarındaki farklılaşma göz önünde bulundurulduğunda, uygulanan NVR programının ebeveynlerin içinde bulundukları aile ve toplumsal yapıda kendilerini daha yeterli hissetmelerine ve anne babalık rollerine ilişkin dengeleme becerilerinin artmasına yardımcı olduğu görülmektedir. Bu sonucun programın hedefleri ile örtüştüğü söylenebilir.

Öte yandan rol doyumu ve yatırım alt ölçeklerinde anlamlı bir farklılaşma görülmemektedir. Ebeveynler ile süreç boyunca, toplum ve sosyo kültürel yapının ebeveynler üzerine yüklediği pek çok rol ve sorumlulukların program içersinde sıkça vurgulanması ve tartışılmasının sonuçlar üzerinde etkili olabileceği düşünülmektedir. Çünkü anne-babalık dünyadaki en zor görevlerden biridir ve programa daha çok annelerin katılması göz önünde bulundurulduğunda, anneler üzerinde oluşan aşırı sorumluluklar ve oluşan stres zaman zaman kaldırılamayacak boyutlara ulaşabilmektedir. Ergen çocuğu olan yetişkin bireyler, bir yandan çocuklarının gelişimi, geleceği ile ilgilenirken, öte yandan içinde bulundukları gelişim dönemlerinin getirdiği sağlık, cinsellik, çift ilişkileri gibi sorumluluklarla baş başa kalabilmektedir. Diğer taraftan da bu aşamadaki ebeveynler köken ailesinde kendi ebeveynlerinin sağlık ve diğer sorunları ile de ilgilenmek durumunda kalabilmektedirler. Tüm bu değişkenlerin ebeveynlerin rol doyumu ve çocuklarının geleceğine dair yatırım algılarını olumsuz yönde etkileyebileceği ve bu nedenle de uygulanan programdan olumlu yönde etkilenmelerini azaltabileceği düşünülebilir.

NVR programının uygulandığı deney grubu ebeveynlerinin, kontrol grubunda yer alan ebeveynlerle karşılaştırıldığında ADÖ son test toplam puan ortalamalarının kontrol grubundaki ebeveynlere göre olumlu anlamda düştügü görülmektedir. Sonuç olarak, şiddetsiz karşı koyma programına katılmış olan deney grubu ebeveynlerinin aile değerlendirme ölçeği toplam puanlarındaki düşüşün uygulanan eğitim programına bağlı olduğu söylenebilir. Yapılan analizler sonucunda bu etkinin son ölçümden iki ay sonra yapılan izleme testi ölçümünde de devam ettiği görülmüştür.

Şiddet ve yıkıcı davranışlara sahip küçük ya da ergen çocuğu olan pek çok ebeveynin bu davranışlarla baş etmekte güçlük yaşadığı ve ebeveyn olarak kendilerinin ya da çocuklarının 
yardım için uzmanlara ya da grup eğitim çalışmalarına katıldığı pek çok çalışmada vurgulanmıştır. Araştırma kapsamında grup programlarına katılan ebeveyn ve ergenler aile ilişkilerinde ve etkileşim biçimlerinde farklılaşma olduğunu program sonunda yapılan bireysel görüşmelerde de vurgulamışlardır. Ebeveyn ve ergenler hem kendilerinin hem de aile üyelerinin programa katılmış olmasının birbirlerini anlamak konusunda çok yardımcı olduğunu ve aile ilişkilerine çok katkı sağladığını belirtmişlerdir. Bu araştırma bulguları literatürde yer alan pek çok araştırma sonuçları ile paralellik göstermektedir (Bal ve Bedel, 2015; Michelson, Ben-Zion, James, Draper, Penney ve Day, 2014; Newman, Fagan ve Webb, 2014; Omer, Steinmetz, Carthy, Schlippe, 2013; Lav1-Levav1, Shachar ve Omer, 2013; Li, Chan, Mak, \& Lam, 2013; Onaylı ve Erdur Baker, 2013; Kabasakal; 2013; EpliKoç, 2013; Lebowitz, Dolberger, Nortov, Omer, 2012; Winter, Morawska \& Sanders, 2012; Y1lmaz Bolat 2011; Akgün, 2008; Omer, Schorr-Sapir ve Weinblatt, 2008; Weinblatt ve Omer, 2008; Barcenas, 2005, Bushfield, 2004; Naik-Polan, 2004; Omer, 2001; Kabasakal, 2001).

Araştırma bulguları incelendiğinde NVR'nin uygulandığı deney grubu ebeveynlerinin, kontrol grubunda yer alan ebeveynlerle karşılaştırıldığında 'Anne Baba Stres Düzeyi Ölçeği' son test puan ortalamalarının kontrol grubundaki ebeveynlere göre düştüğü görülmektedir. Sonuç olarak, şiddetsiz karşı koyma programına katılmış olan deney grubu anne-babalarının anne-baba stres ölçeği puanlarındaki düşüşün uygulanan ebeveyn beceri programına bağlı olduğu söylenebilir. Yapılan analizler sonucunda bu etkinin son ölçümden iki ay sonra yapılan izleme testi ölçümünde de devam ettiği görülmüştür.

Araştırmanın sonuçları, ülkemizde ve yurt dışında yapılan bazı çalışmalarla paralellik göstermektedir (Omer, 2001; Pervez-Nieves, 2001; Östberg, 2005; Omer \& Weinblatt, 2008; Omer, Schorr-Sapir ve Weinblatt, 2008; Şahin ve Kalburan, 2009; Lebowitz, Dolberger, Nortov, Omer, 2012; Canbolat, 2012; Omer, Steinmetz, Carthy, Schlippe, 2013; LaviLevavi, Shachar, Omer, 2013; Çekiç, 2015). Şahin ve Kalburan (2009) yurt dışında uygulanan farklı aile eğitimlerinin etkililiğini inceledikleri meta analitik çalışmada, uygulanan programların sonunda ebeveynlerin anne-babalık davranışlarının olumlu yönde değiştiği; anne-babalıkla ilgili stres düzeylerinin düştüğü ve özyeterlilik duygularının yükseldiğini belirlemiştir. Ayrıca aile eğitimi programlarının ebeveynlerin çocukla iletişimi ve çocuk bakımı konularında olumlu etkileri saptanmıştır. Bu sonuçlar, bu araştırmanın bulguları ile paralellik göstermektedir.

Sonuç olarak bu araştırmada, Türk kültüründe yapılan deneysel çalışmalardan farklı olarak anne baba ve ergenler birlikte ele alınarak çalışılmıştır. Saldırgan davranışlar, ergenlerin yaşamları süresince edinmiş oldukları, problem çözme ve baş etme stratejisi olarak kullandıkları davranış örüntüleridir. Öğrenciler, özellikle de saldırgan davranışların sıkça görüldügüu, bu davranışların etkili bir problem çözme yöntemi olarak kabul edildiği, bu tür davranışların desteklendiği bir ortamda bulunuyorlarsa, bu baş etme yöntemlerinden vazgeçmeleri onları korunaksız hale getirebilmektedir. Öğrencilerin bu davranışlardan vazgeçmeleri için yerlerine daha etkili beceri ve davranışlar koymaları gerekmektedir (Gültekin, 2008).

Kritik bir gelişim aşaması olan ergenlik döneminde yoğun olarak görülen şiddet ve saldırganlığın azaltılmasında, hem ergenler hem de onların ebeveynleri ile birlikte çalışıldığ araştırmaların ülkemizde pek yapılmadığı da dikkate alındığında, bütüncül bir bakış açısıyla hazırlanmış bu programın ülkemizde, ileride uygulanacak diğer araştırmalar için başlangıç olacağı ve onlara katkıda bulunacağı söylenebilir. Bu bilgiler çerçevesinde, ülkemizde ve dünyada önemli sorunlar arasında yer alan şiddet ve saldırganlık içeren tutum ve davranışların azaltılması konusunda ergen bireylerle çalışırken konunun çok boyutlu, 
kapsamlı bir biçimde ele alınması ve özellikle aileler olmak üzere öğretmenler ve idareciler gibi konunun diğer paydaşlarının dahil olduğu önleyici, koruyucu ve müdahale edici programların geliştirilerek uygulanmasının yararlı olacağı düşünülmektedir. Bu kapsamda özellikle ebeveyn yeterlikleri ve aile etkileşimleri üzerine odaklanan şiddetsiz karşı koyma ebeveyn eğitim programı da mevcut programlara ek olarak kullanılabilir.

Son olarak araştırmanın çalışma grubu Adana'da bir ortaöğretim okulunda eğitimine devam eden öğrenci ve onların ebeveynlerinden oluşmaktadır. Elde edilen bulgular, ancak benzer eğitim ve sosyo-kültürel yapıdaki gruplara genellenebilir ve veriler uygulanan ölçeklerin ölçtüğü özelliklerle sınırlıdır. 


\section{KAYNAKÇA}

ABER, J. L., Brown, J. L., \& Jones, S. M. (2003). Developmental trajectories toward violence in middle childhood: Course, demographic differences, and response to school-based intervention. Developmental Psychology, 39(2), 324-348.

AKDENIZ, M. (2007). Öfke kontrolü eğitiminin lise ögrrencilerinin öfke kontrolü becerilerine etkisi. Yayınlanmamış Yüksek Lisans Tezi, Çukurova Üniversitesi, Adana.

AKGÜN, E. (2008). Anne-Çocuk ilişsisini oyunla geliştirme eğitiminin anne-çocuk etkileşim düzeyine etkisi. Yayımlanmamış doktora tezi, Ankara Üniversitesi Eğitim Bilimleri Enstitüsü, Ankara.

AKGÜN, S., ARAZ, A.,\& KARADAĞ, S. (2007). Anlaşmazlıklarımızı çözebiliriz: ilköğretim öğrencilerine yönelik bir çatışma çözümü eğitimi ve psiko-sosyal etkileri. Türk Psikoloji Dergisi, 22(59), 43-62.

ANDO, M., ASAKURA, T., Ando, S., \& Simons-Morton B. (2007). A psychoeducational program to prevent aggressive behavior among Japanese early adolescents. Health Education and Behavior, 34, 765-76.

ARKAN, B.,\& ÜSTÜN, B. (2009). Davranım bozukluğu olan çocuklara psikiyatrik yaklaşımda anne-baba eğitim programları: İki örnek bağlamında bir değerlendirme. Psikiyatride Güncel Yaklaşımlar-Current Approaches In Psychıatry, 1, 155-174.

BAL, A. \& BEDEL, A. (2015). The Effect of Family Counseling Training on the Relationship between Mother-Father and the Child. The Online Journal of Counseling and Education, 4(3), 1-14.

BACIOĞLU, S.D. (2014) Şiddet ve Saldırganlığın azaltılmasında önleme ve müdahale programlarının etkililiği: meta analiz çalışması. Türk Psikolojik Danışma ve Rehberlik Dergisi, 5 (42), 294-304

BARCENAS, M. G. (2005). Parenting education curriculum for parent educators at public schools. Doktora Tezi, California State University, Long Beach, USA.

BEDEL, A.,\& ARI, R. (2011). Kişiler arası sorun çözme beceri eğitiminin yetiştirme yurdunda yaşayan ergenlerin yapıcı problem çözme ve sürekli öfke düzeylerine etkisi. Pegem Ĕgitim ve Ögretim Dergisi, 1(4), 1-10.

BOLAT-KARATAŞ, Z. (2002). Anne baba saldırganlı̆̆ ile lise öğrencilerinin saldırganlı̆̆ arasındaki ilişkinin incelenmesi. Yayımlanmamış Yüksek LisansTezi, Çukurova Üniversitesi, Adana.

BULUT, I. (1990). Aile değerlendirme ölçeği el kitabı. Ankara: Özgüzeliş Matbaası.

BUSS, A.H., \& PERRY, M. (1992). The Aggression Questionnaire. Journal of Personality and Social Psychology, 63, 452-459.

BUSS, A. H.,\& WAREN, W.L. (2000). Aggression questionnaire: Manual. Los AngelesCA: Western Psychological Services.

BUSHFIELD, S. (2004). Fathers in prison: Impact of parenting education. The Journal of Correctional Education. 55(2), 139-147.

BÜYÜKÖZTÜRK Ş. (2007). Deneysel desenler öntest-sontest kontrol grubu desen ve veri analizi (2. baskl). Ankara: Pegem A Yayıncılık.

CAN, S. (2002). Aggression questionnaire adll ölçeğin Türk popülasyonunda geçerlik ve güvenirlik çalışması. Yayınlanmamış Uzmanlık Tezi, Gülhane Askeri Tıp Akademisi, Ruh Sağlığı ve Hastalıkları Servisi Şefliği, İstanbul.

ÇEKİÇ, A. (2015) Akılcı duygusal davranışçı yaklaşıma dayalı olarak geliştirilen aile eğitim programinın anne babaların akılcı olmayan inançlarının ve anne babalık 
streslerinin azaltılması üzerinde etkililiği. Yayınlanmamış Doktora Tezi, Çukurova Üniversitesi, Adana.

DODGE, K.A.,\& Frame, C.L. (1982) Social Cognitive Biases and Deficits in Aggressive Boys. Child Development,53, 620-635.

DURAN, Ö.,\& Eldeleklioğlu, J. (2005). Öfke kontrol programının 15-18 yas arası ergenler üzerindeki etkililiğinin araştırılması. Gazi Egitim Fakültesi Dergisi, 25(3), 267-280.

ELIZABETH D. \& ELISABETH H. (2010). Non-violent resistance programme: Guidelines for parents, care staff and volunteers working with adolescents with violent behaviours. Publisher: Pavilion Publishing (Brighton) Ltd.

EPSTEIN, K., BALDWIN, L. M., \& Bishop, D. S. (1983). The McMaster family assessment device. Journal of Marital and Family Therapy, 9(2), 171-180.

FREEDMAN, J.L., Sears, D.O., \& Carlsmith, J.M. (2003). Sosyal psikoloji. (Çev. A. Dönmez), Ankara: İmge Kitabevi.

FONG, J. (2006). Psychodrama as a preventive measure: Teenage girls confronting violence. Journal of Group Psychotherapy, Psychodrama and Sociometry, 59(3), 99-108.

GLADDING, S.T. (2012). Aile terapisi. tarihi, kuram ve uygulamalart. İ. Keklik ve İ. Yıldırım (Çev. Ed.). Türk Psikolojik Danışma ve Rehberlik Derneği Yayınları: Ankara.

GÜLER, M.,\& Yetim, Ü. (2008). Ebeveyn rolüne ilişkin kendilik algısı ölçeği: Geçerlik ve güvenirlik çalışması. Türk Psikoloji Yazıları, 11(22), 34-43.

GÜLTEKIN, F. (2008). Saldırganlık ve öfkeyi azaltma programının ilköğretim ikinci kademe ögrencilerinin saldırganlık ve öfke düzeyleri üzerindeki etkisi. Doktora Tezi, Hacettepe Üniversitesi, Ankara.

GÜNDOĞDU, R. (2009). Yaratıcı drama temelli çatışma çözme programının ergenlerde öfke, saldırganlı ve çatışma çözme becerilerine etkisi. Doktora Tezi, Selçuk Üniversitesi, Konya.

GÜNER, İ. (2007). Çatışma çözme becerilerini geliştirmeye yönelik grup rehberliğinin lise ögrencilerinin saldırganlı ve problem çözme becerileri üzerine etkisi. Yayınlanmamış Yüksek Lisans Tezi, Malatya.

HERRMANN, D. S.,\& MCWHIRTER, J. J. (2001). SCARE: student created aggression replacement education, anger reduction for students. Dubuque: Kendall/HuntPublishing Company.

KABASAKAL, Z. (2013). The effects of mother education programs on the functionality, anger management and conflict solution levels of families. EgitimArastirmalartEurasian Journal of Educational Research, 52, 1-20.

KARATAŞ, Z.,\& GÖKÇAKAN, Z. (2009). Psikodrama teknikleri kullanılarak yapılan grup uygulamalarının ergenlerde saldırganlığı azaltmadaki etkisinin incelenmesi. Türk Psikiyatri Dergisi,20(4), 357-366.

KAYMAK-ÖZMEN, S. (2013). Anne-baba eğitimi programının çocuklardaki davranış sorunları ve anne-babaların depresyon düzeylerine etkisi. Eğitim ve Bilim, 38(167), 98-113.

KULAKSIZOĞLU, A. (2004). Ergenlik psikolojisi (6.basım). İstanbul: Remzi Kitabevi.

KUZGUN, Y.,\& HAMAMCI Z. (2007). Anababa eğitim programları. Ankara: Maya Akademi Yayınları.

LAVI-LEVAVI, I.,SHACHAR, I., \& Ömer, H. (2013). Training in nonviolent resistance for parents of violent children: Differences between fathers and mothers. Journal of Systemic Therapies,32(4), 79-93.

LEBOWITZ, E. R., DOLBERGER, D., NORTOV, E., \& OMER, H. (2012). Parent training in non violent resistance for adult entitled dependence. Family Process, 51, 1-17. 
MACPHEE D., BENSON, J. B.,\& BULLOCK D. (1986). Influences On Maternal SelfPerceptions. Paper presented at theFifthBiennial International Conference on Infant Studies, Los Angles.

MCWHIRTER, J.J., MCWHIRTER, B. T., MCWHIRTER, E. H., \& MCWHIRTER, R. J. (2004). Atrisk youth. Belmont: Thomson Brooks Cole.

NAIKK-POLAN, A. J. (2004). The effectiveness of a dyadic parent training intervention with high risk families: generalization to the home. Doktora Tezi, DePaul University, Chicago, Illinois, USA.

OMER, H. (2001). Helping parents deal with children's acute disciplinary problems without escalation: The principle of non-violent resistance. Family Process, 40, 53-66.

OMER, H. (2004). Nonviolent resistance: A new approach to violent and self-destructive children. Cambridge: Cambridge University Press.

OMER, H., \& Weinblatt, U. (2008). Nonviolent Resistance: A Treatment for Parents of Children with Acute Behavior Problems. Journal of Marital and Family Therapy 34(1):75-92.

ÖSTBERG, M. (2005). Can a child-problem focused intervention reduce mothers' stress? Parenting: Science and Practice. 5(2), 153-174.

ÖZMEN S. K.,\& ÖZMEN A. (2012).Anne baba stres ölçeğinin geliştirilmesi. Millı̂ Eğitim Yayinlarl, 41(196), 20.

ROLLIN S., A., ULREY-KAISER C., POTTS I., \& CREASON A. H. (2003). A schoolbased violenceprevention model for at risk eighth grade youth. Psychology in the School,40(4),403-416.

SCHRUMPF, F., CRAWFORD, K.D.,\& BODİNE, J.R. (2007). Okulda Çatışma Çözme ve Akran Arabuluculuk Program Rehberi. Ankara: İmge Kitapevi. 1. Bask1.

ŞAHIN \& KALBURAN, (2009) Aile eğitim programları ve etkililiği: Dünyada neler uygulanıyor? Pamukkale Üniversitesi Ĕ̈itim Fakültesi Dergisi,1(1) 25. Sayı 41.

TAŞTAN, N. (2004). Çatışma çözme ve akran arabuluculuğu eğitimi programlarının ilköğretim altıncı sınıf öğrencilerinin çatışma çözme ve akran arabuluculuğu becerilerine etkisi. Doktora Tezi, Ankara Üniversitesi, Ankara.

TEKINSAV-SÜTÇÜ, G. S. (2006). Ergenlerde öfke ve saldırganlığı azaltmaya yönelik bilişsel davranışçı bir müdahale programının etkililiğinin değerlendirilmesi. Yayınlanmamış Doktora Tezi, Ege Üniversitesi, İzmir.

TÜRNÜKLÜ, A., KAÇMAZ, T., İKIZ, E.,\& BALCI, F. (2009). Anlaşmazlık çözümü, müzakere ve akran-arabuluculuk eğitim programı. Ankara: Maya Akademi.

UYSAL, Z. (2006). Çatışma çözme eğitim programının ortaögretim dokuzuncu sınıf düzeyindeki öğrencilerin çatışma çözme becerilerine etkisi. Yüksek Lisans Tezi, Çukurova Üniversitesi, Adana.

WILSON, S. J.,\& MARK, W. L. (2007). Update of a meta-analysis of school-based intervention programs. American Journalof Preventive Medicine, 33(2),130-143 